\title{
Combined thermal analysis of plant oils
}

\author{
Kinga Tamási ${ }^{1} \cdot$ Kálmán Marossy ${ }^{1,2}$ (])
}

Received: 30 June 2020 / Accepted: 3 December 2020 / Published online: 6 February 2021

(c) The Author(s) 2021

\begin{abstract}
The paper deals with the study of seven selected natural plant oils. Differential scanning calorimetry (DSC), dynamic mechanical analysis (DMA) and thermally stimulated discharge (TSD) methods were used. It has been found that most of the oils tested are in a glassy state at low temperature and have multiple transitions in the low temperature range. DSC shows complex melting-like processes or glass transition. For both DMA and TSD, the scaffold supportive method was used and found as a suitable one. DMA and TSD proved more sensitive than DSC and revealed at least two transitions between - 120 and $-40{ }^{\circ} \mathrm{C}$. In the case of three oils (argan, avocado and sunflower), current reversal was observed by TSD; this symptom cannot be fully explained at the moment.
\end{abstract}

Keywords Plant oils · DSC · Dynamic mechanical analysis (DMA) · Thermally stimulated discharge (TSD)

\section{Introduction}

Polymeric materials from renewable resources have been in the focus of attention in recent years. Plant oils are vegetable-based triglycerides extracted from the seed, nut, kernel or fruit of various plant species. Applications for plant oils exist in numerous industries, including but not limited to the food, nutritional supplement, personal care, cosmetic, plastic industries, etc. Ecological factors are continuously gaining importance in our society; the subjective criteria are the most environmental compatibility between additives and polymers. Vegetable oils have been used as lubricants [1-3] and plasticizers [4-6] in their natural or epoxidized forms. In this research, we investigated seven different plant oils: argan, avocado, castor, rapeseed (canola), olive, palm and sunflower oils.

Liquefaction or melting point of plant oils is as used in chemistry (also known as freeze point and glass transition point), and this is the temperature at which a given solid material changes from a solid to a liquid state, or melts [7]. Thermodynamically, the pour point (or melting point) can vary by temperature $(\mathrm{T})$ and pressure $(\mathrm{P})$ or both $(\mathrm{T}-\mathrm{P})$. Pour

Kálmán Marossy

polka101@uni-miskolc.hu

1 University of Miskolc, Miskolc, Egyetemváros 3515, Hungary

2 Borsodchem Zrt, Bolyai tér 1, Kazincbarcika 3700, Hungary point is an important property of plant oils; this parameter is usually used to characterize them in the food and lubricant industries. In the literature, numerous studies deal with the information about pour points, but in most cases without the description of applied measurement methods. One of the most widely used methods for determining the pour point of fluids and oils is differential scanning calorimetry (DSC). Tseretely [8] found glass transitions in gelatins using DSC. While DSC is easy to use for the investigation of fluid substances, mechanical and electrical methods are hardly ever applied. Corriea [9] tested low molecular weight liquids and glassy solids, such as phenyl salicylate, glycerol and maltitol, by TSD and resolved the relaxation processes by thermal sampling method. Bansak [10] used a high-frequency AC dielectric method in the $10 \mathrm{MHz}$ to $3 \mathrm{GHz}$ range for the determination of relaxation processes of rapeseed oil. However, the effective frequency of TSD is at least 10 orders of magnitude lower; therefore, TSD has a much better resolving power [11] than the AC dielectric one.

Vegetable oils are characterized also by the fatty acids that constitute the triglycerides. All triglyceride molecules can be broken down into a molecule of glycerol and three molecules of fatty acid. The chain length, degree and position of the unsaturated bond vary greatly depending on the type of oilseed from which the oil was extracted. Presumably, the different fatty acid contents of plant oils will cause different relaxation processes during the DSC, DMA and TSC investigations. 


\section{Experimental}

\section{Materials}

All oils tested were commercial products. The list of oils is given in Table 1. This table also contains the published melting (freezing, pour) points and the actual fatty acid content as well. Fatty acid composition of tested oils was determined by gas chromatography after transesterification with methanol [12].

For TSD measurements, $60 \mathrm{gm}^{-2}$ borosilicate glass fiber filter of $0.2 \mathrm{~mm}$ thickness and $2.6 \mu \mathrm{m}$ nominal pore size and $87 \pm 2 \%$ pore volume (SIGMA F7769) was used as scaffolding material described in $[13,14]$.

For DMA tests, $1.6-\mathrm{mm}$-thick $150 \mathrm{gm}^{-2} 80 \%$ viscose $20 \%$ natural cellulose-based non-woven textile (Suprawisch, Germany) was used as a scaffold. Its pore volume is $92 \pm 3 \%$. Figure 1 shows the SEM image of this textile.

\section{Instruments and test methods}

For DSC measurements a Mettler Toledo DSC 823e instrument was used with about $10 \mathrm{mg}$ sample in a standard 40 $\mu \mathrm{L}$ aluminum crucible. The tests were carried out in the temperature range of -120 to $20{ }^{\circ} \mathrm{C}$ with liquid nitrogen

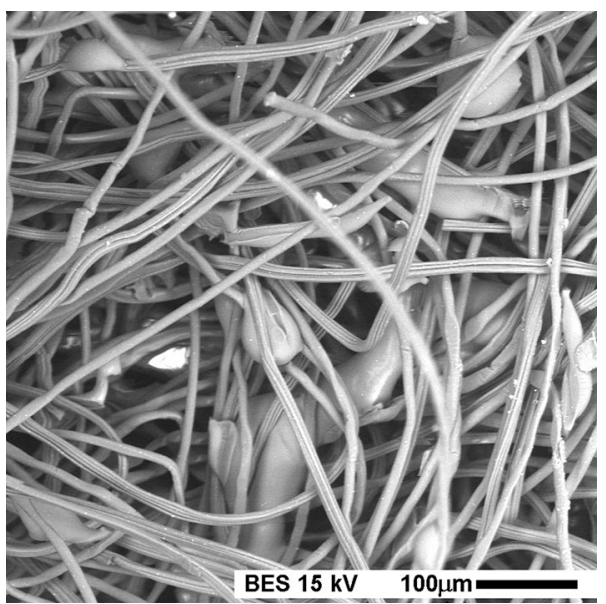

Fig. 1 SEM image of cellulose-based non-woven textile used as scaffold material for DMA. (Nominal magnification: $150 \times$ )

cooling using a heating rate of $10{ }^{\circ} \mathrm{C} \mathrm{min}^{-1}$. Heat flow was plotted by the standard software of the instrument then redrawn.

Dynamic mechanical measurements were carried out with a Rheometric Scientific DMTA MK-III instrument in single cantilever mode at $1 \mathrm{~Hz}$ frequency and $64 \mu \mathrm{m}$ peakto-peak amplitude. Heating rate was $2{ }^{\circ} \mathrm{C} \mathrm{min}^{-1}$. The specimens were textile strips soaked with the plasticizer to be tested. Because the thickness and oil quantity are not exactly
Table 1 List of plant oils tested, their published melting points and three fatty acid components of highest concentration determined by GC-MS

\begin{tabular}{lllll}
\hline Name CAS No & Abbrev & Published melting point $/{ }^{\circ} \mathrm{C}$ & $\%$ & $\begin{array}{l}\text { Composi- } \\
\text { tion fatty } \\
\text { acid }\end{array}$ \\
\hline Rapeseed (canola) oil 8002- & rape & $-10[16,17]$ & & oleic \\
13-9/ 120962-03-0 & & $-18[18]$ & 61 & linoleic \\
& & $-31.7[19]$ & 21 & palmitic \\
Argan oil 223747-87-3 & arga & $2[20]$ & 4 & oleic \\
& & $5[21]$ & 43 & linoleic \\
Avocado oil 8024-32-6 & avoc & $9[22]$ & 37 & palmitic \\
& & $8[23]$ & 12 & oleic \\
& & $-11[24]$ & 70 & palmitic \\
Castor oil 8001-79-4 & cast & $-16[25]$ & 20 & linoleic \\
& & $-18[16]$ & 10 & ricinoleic \\
Olive oil 8001-25-0 & & $-26.2[26]$ & 94 & oleic \\
& oliv & $-6[16,17]$ & 4 & linoleic \\
& & $-9[27]$ & 2 & oleic \\
Palm oil (fat) 8002-75-3 & palm & $-10[28]$ & 70 & palmitic \\
& & $35[16,17,29]$ & 14 & linoleic \\
& & $25[30]$ & 13 & palmitic \\
& & $31.7[19]$ & 42 & oleic \\
Sunflower oil 8001-21-6 & sun & $-17[16,17]$ & 41 & linoleic \\
& & $-18[27]$ & 59 & linoleic \\
& & $-12[18]$ & 30 & oleic \\
& & & 6 & stearic \\
\hline
\end{tabular}


known, the modulus cannot be calculated accurately. However, the relative error is the same for both E' and for E"; therefore, the mechanical loss factor $(\operatorname{tg} \delta)$ is exact.

Setaram TSCII instrument was used for the TSD measurements with a cell supplied with that instrument [14]. Borosilicate glass filter disks of $7 \mathrm{~mm}$ diameter were soaked with the plasticizer and put into the standard cell. The weight of the glass filter is $2.3 \mathrm{mg}$ saturated with about 8 to $10 \mathrm{mg}$ plant oil. Polarization temperature was $50{ }^{\circ} \mathrm{C}$, cooling to $-120^{\circ} \mathrm{C}$ under $500 \mathrm{~V} \mathrm{~mm}^{-1}$ field. Both cooling and heating rates were $5{ }^{\circ} \mathrm{C} \mathrm{min}^{-1}$; the heat transfer medium was helium gas. More details of the test, the instrument and the evaluation method are described in [15].

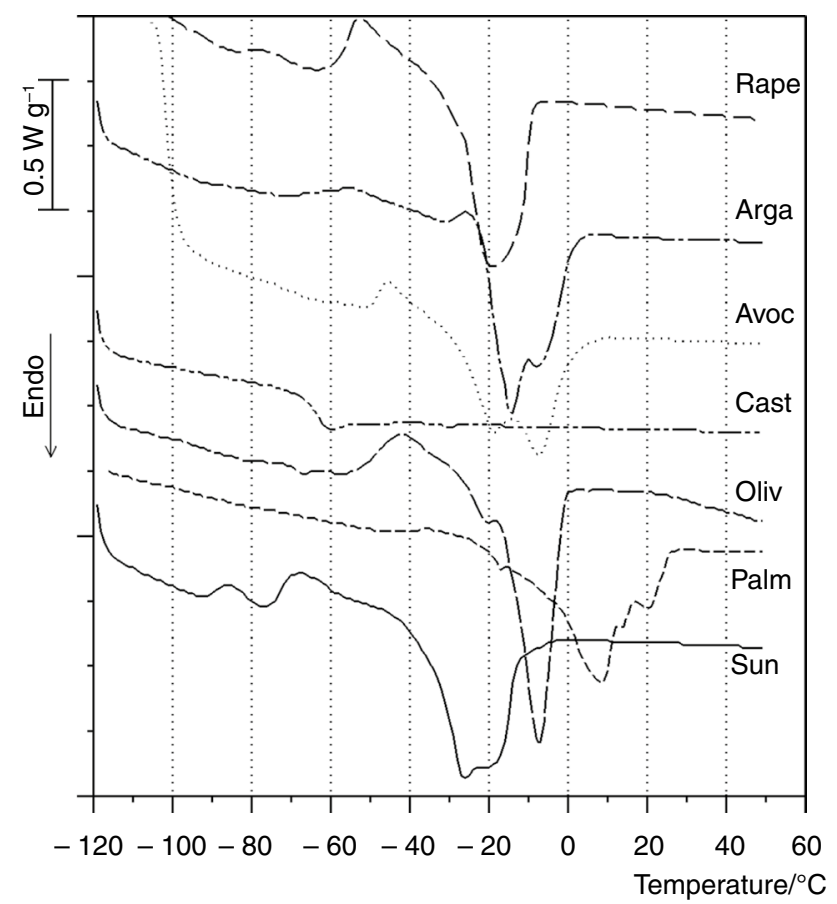

After transesterification, fatty acid methylesters were obtained as solutions in n-hexane. By the gas chromatographic analysis, the solutions were performed with an Agilent 7890 (5975C) GC-MS instrument using RT 2560 column and helium carrier gas. (fatty acids below $1 \%$ are not listed in Table 1).

\section{Results}

\section{Differential scanning calorimetry (DSC)}

DSC results of the seven oils tested are summarized in Fig. 2. DSC curve of castor oil shows regular glass transition at $-63{ }^{\circ} \mathrm{C}$; curves of the other oils show melting-like endothermic peaks. These peaks are complex, at least doublets. It is unambiguous in the case of argan, avocado and sunflower oil but even the DSC curve of rapeseed oil must be a composite one. Resolving of these processes was not carried out, but temperatures of two maxima are listed in Table 2, if any. The DSC curves with exception of sunflower oil do not contain any evaluable transition below $-60^{\circ} \mathrm{C}$.

\section{Dynamic mechanical analysis (DMA)}

In the case of DMA tests, the mechanical loss factor $(\operatorname{tg} \delta)$ versus temperature curves are plotted in Fig. 3 shifted over each other. Interestingly, these curves show multiple transitions; $\operatorname{tg} \delta$ curves contain three maxima and two maxima, that is, two processes below $-40^{\circ} \mathrm{C}$. The exception is the castor oil as in the case of DSC as well. It shows a single, strong glass transition in accordance with DSC. The peak temperature is higher than the midpoint of the DSC step; however, dynamic methods always result in higher values because of the higher effective frequency. The flat low temperature part of $\operatorname{tg} \delta$ of castor oil proves that the low-temperature peaks

Fig. 2 DSC curves of plant oils tested

Table 2 Most characteristic transitions found in tested plant oils

\begin{tabular}{|c|c|c|c|c|c|c|c|c|c|c|c|c|}
\hline \multirow[t]{2}{*}{ Abbrev } & \multicolumn{2}{|c|}{$\begin{array}{l}\mathrm{DSC} \\
\text { peaks } /{ }^{\circ} \mathrm{C}\end{array}$} & \multicolumn{4}{|c|}{ DMA $\operatorname{tg} \delta$ peaks $/{ }^{\circ} \mathrm{C}$} & \multicolumn{4}{|c|}{ Characteristic TSD peaks ${ }^{c}$} & \multicolumn{2}{|c|}{$\begin{array}{l}\text { Current } \\
\text { rev. } /{ }^{\circ} \mathrm{C}\end{array}$} \\
\hline & & & & & & & $\vartheta_{\max } /{ }^{\circ} \mathrm{C}$ & $\Delta \varepsilon$ & $\vartheta_{\max } /{ }^{\circ} \mathrm{C}$ & $\Delta \varepsilon$ & From & To \\
\hline rape & -18 & - & -88.6 & -59.2 & -11.4 & - & -89 & 0.81 & -7.4 & 2.35 & - & - \\
\hline $\operatorname{arga}$ & -14 & -7 & -89.8 & -54.6 & -5.1 & - & -67.5 & 0.36 & -5.6 & 1.90 & -59 & -21 \\
\hline avoc & -18 & -7 & -89.1 & $-50.7^{\mathrm{b}}$ & -7.6 & 27.3 & -67.5 & 0.69 & - & - & -41 & -34 \\
\hline cast & $-63^{\mathrm{a}}$ & - & - & - & -49.8 & - & -62.5 & 2.89 & -14.5 & 1.45 & - & - \\
\hline oliv & -7 & -20 & -84.0 & -49.2 & -3.9 & - & -86 & 0.61 & +8.3 & 2.19 & - & - \\
\hline palm & 9 & 20 & $-85.7^{\mathrm{b}}$ & $-48.5^{\mathrm{b}}$ & 17.1 & 30.5 & -64.9 & 0.40 & +27.4 & 7.10 & - & - \\
\hline sun & -26 & -20 & -93.8 & $-64.3^{b}$ & -15.0 & - & -93.1 & 0.49 & -11.4 & 4.72 & -66 & -35 \\
\hline
\end{tabular}




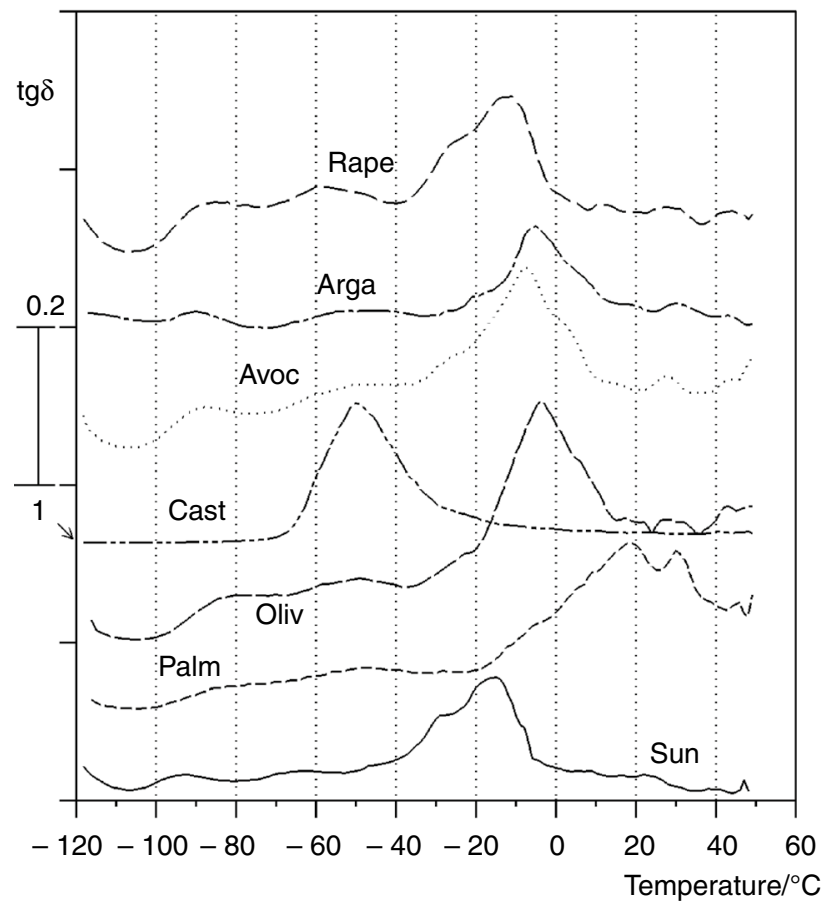

Fig. 3 DMA mechanical loss factor $(\operatorname{tg} \delta)$ curves of plant oils tested. (For castor oil, the scale bar is 1 !)

cannot originate from the cellulose scaffold. (The apparent $\mathrm{E}^{\prime}$ of neat cellulose scaffold is $1 \mathrm{MPa}$ while its $\operatorname{tg} \delta$ is 0.06 .)

Peak positions of the weak transitions were determined over linear baseline using our peak searching program. DMA peak temperatures are also summarized in Table 2.

\section{Thermally stimulated discharge (TSD)}

All TSD curves are normalized to $1 \mathrm{kV} \mathrm{mm}^{-1}$ polarizing field and $30 \mathrm{~cm}^{2}$ electrode area [15] and are shown in Figs. 4-10; the raw curves are plotted in solid-resolved transitions in different styles: dotted and dashed lines. Although the pore volume of borosilicate scaffold is known $(87 \pm 2 \%$.), further correction was not applied. The depolarization current of the borosilicate filter is less than $1 \mathrm{pA}$ until $0{ }^{\circ} \mathrm{C}$ and less than $5 \mathrm{pA}$ at $50{ }^{\circ} \mathrm{C}$ [14].

TSD has a very low effective frequency; therefore, a good resolving power is expected. Where it was possible, we carried out the resolving transition of the obtained depolarization curves. Two main peaks are listed in Table 2; relaxation strength values contain the $\Delta \varepsilon$ sub-transitions as well. More detailed data of resolved transitions are listed in Table 3.

In the case of three oils (argan, avocado and sunflower), current reversal was also observed. Our evaluation program is not prepared for analysis in such an occurrence. In this case, the calculated relaxation strength is negative. We suppose that some kind of structural rearrangement takes place;

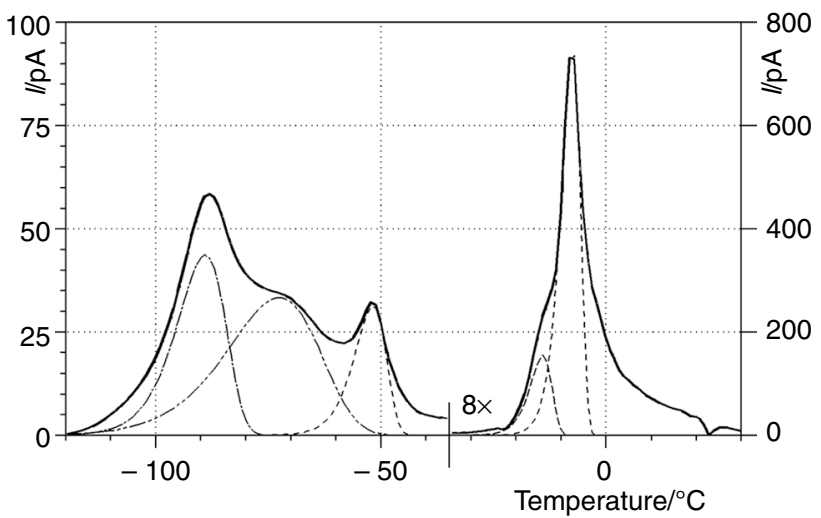

Fig. 4 Resolved TSD depolarization curve of rapeseed oil (Over $-35^{\circ} \mathrm{C}$, the right scale is valid)

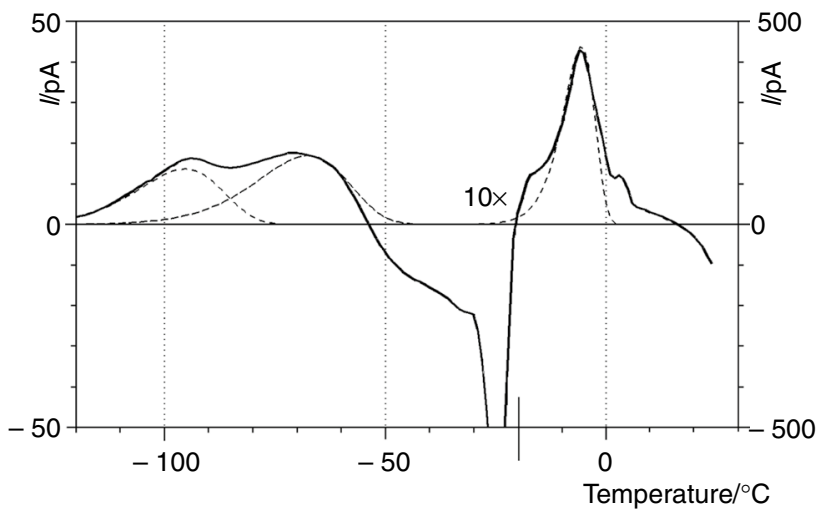

Fig. 5 Resolved TSD depolarization curve of argan oil with current reversal. (Over $-20^{\circ} \mathrm{C}$, the right scale is valid)

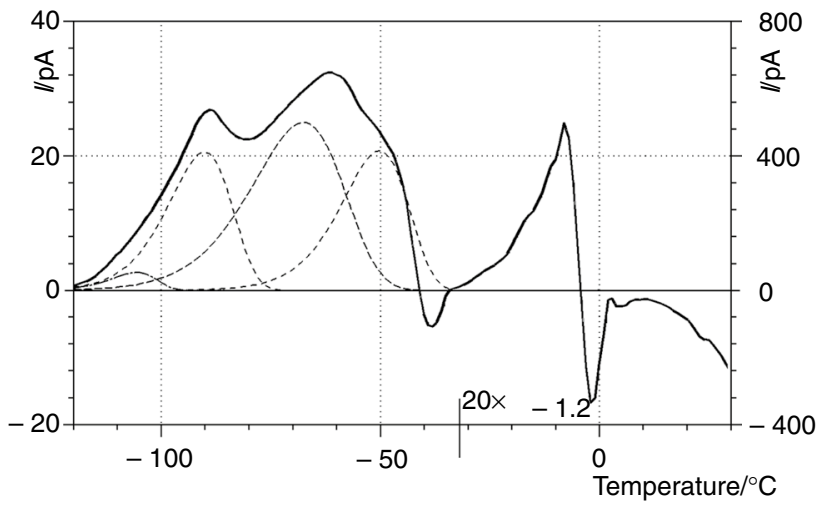

Fig. 6 Resolved TSD depolarization curve of avocado oil with current reversal. (Over $-32^{\circ} \mathrm{C}$, the right scale is valid)

otherwise, it is against the basic laws of physics. Explaining this incident needs further research.

All oils tested have transitions in the low temperature $\left(-120\right.$ to $\left.-50{ }^{\circ} \mathrm{C}\right)$ range. Castor oil also shows low-intensity 


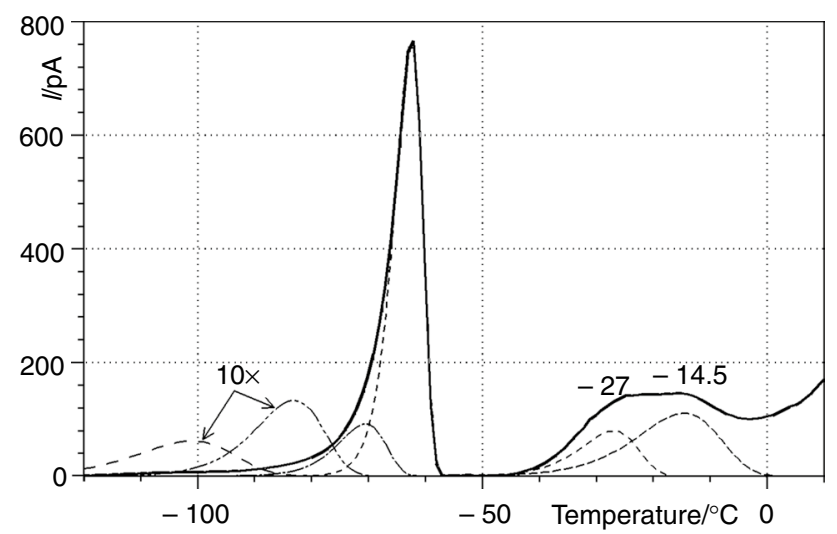

Fig. 7 Resolved TSD depolarization curve of castor oil. (Two lowest temperature peaks are multiplied by 10 for better visibility)

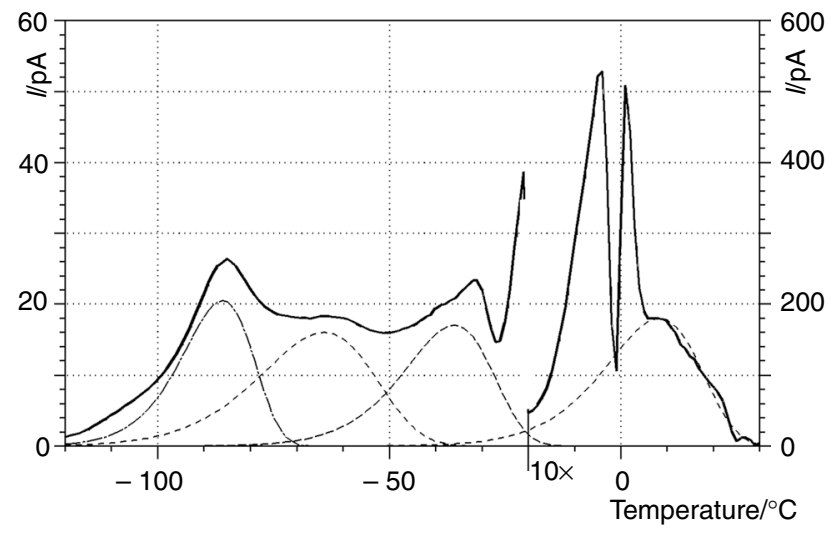

Fig. 8 Resolved TSD depolarization curve of olive oil. (Over $-20{ }^{\circ} \mathrm{C}$, the right scale is valid)

peaks, even as it has shown neither by DSC nor by DMAdetectable transitions. The main transition of castor oil lies at $-63{ }^{\circ} \mathrm{C}$. It is the most uniform triglyceride; more than $90 \%$ of its fatty acids are ricinoleic acid. All other oils have more complex TSD curves. Main transition of palm oil is doubled (s. Fig. 9.), and both transitions are complex.

Palm oil at room temperature is a grease-like solid; accordingly, one of its twin peaks occur in the room temperature range $\left(23.6,27.1^{\circ} \mathrm{C}\right)$.

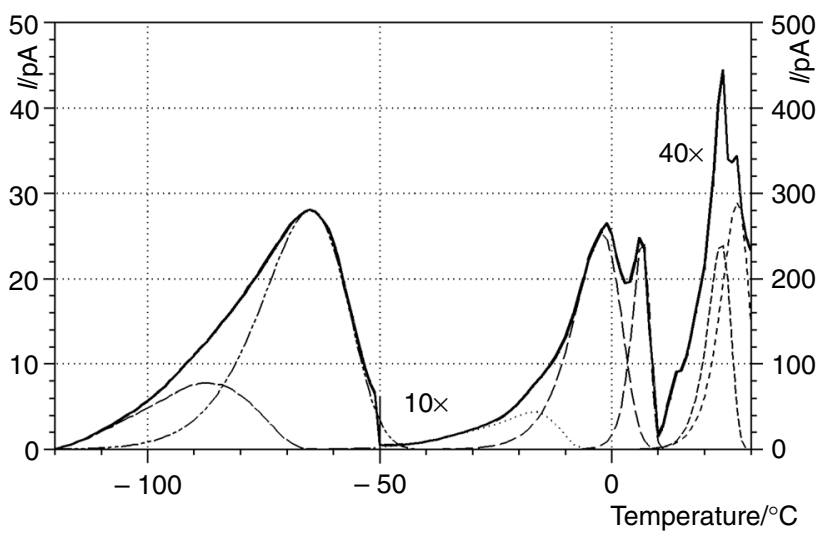

Fig. 9 Resolved TSD depolarization curve of palm oil (fat). (Over $-50{ }^{\circ} \mathrm{C}$, the right scale is valid; over $+10{ }^{\circ} \mathrm{C}$, the scale is 2000pA)

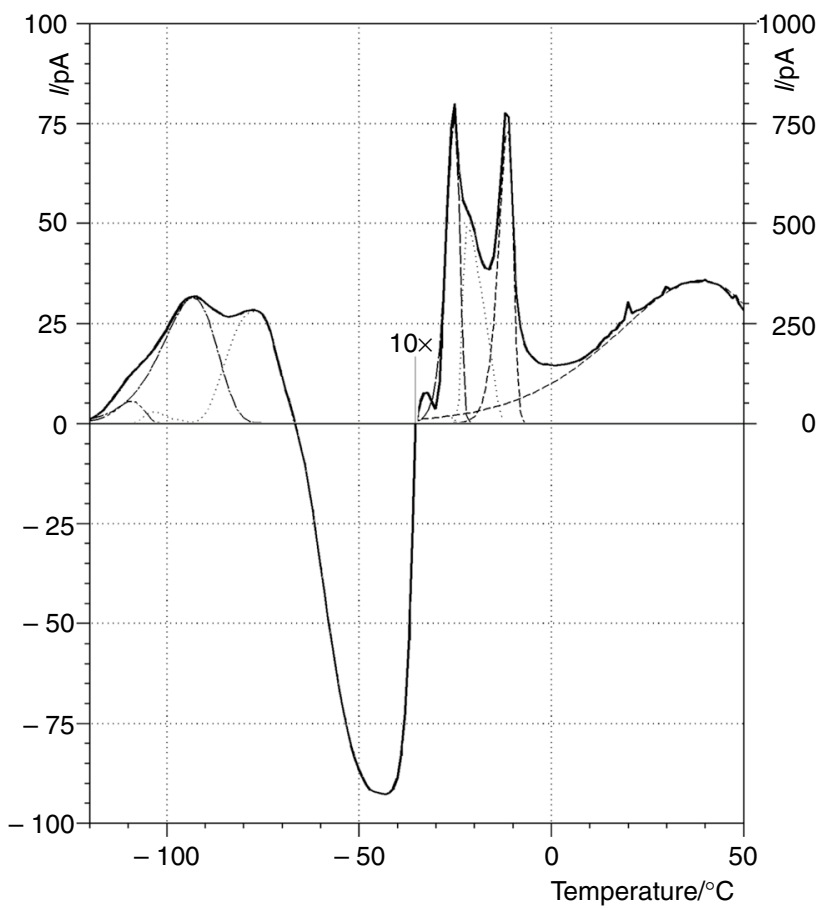

Fig. 10 Resolved TSD depolarization curve of sunflower oil with strong current reversal. (Over $-32{ }^{\circ} \mathrm{C}$ the right scale is valid. The thin-dotted line is not a resolved part) 
Table 3 Resolved peaks of TSD curves

\begin{tabular}{|c|c|c|c|c|c|c|c|c|}
\hline Oil & & 1 & 2 & 3 & 4 & 5 & 6 & 7 \\
\hline \multirow[t]{3}{*}{ rape } & $\vartheta_{\max } /{ }^{\circ} \mathrm{C}$ & & -89 & -72.5 & -51.7 & -14 & -7.4 & \\
\hline & $I_{\max } / \mathrm{pA}$ & & 43.7 & 33.3 & 31.4 & 155 & 750 & \\
\hline & $\Delta \varepsilon$ & & 0.28 & 0.40 & 0.13 & 0.45 & 1.9 & \\
\hline \multirow[t]{3}{*}{ arga } & $\vartheta_{\max } /{ }^{\circ} \mathrm{C}$ & & -95.3 & -67.5 & & & -5.6 & \\
\hline & $I_{\max } / \mathrm{pA}$ & & 13.7 & 17 & & & 440 & \\
\hline & $\Delta \varepsilon$ & & 0.15 & 0.21 & & & 1.9 & \\
\hline \multirow[t]{3}{*}{ avoc } & $\vartheta_{\max } /{ }^{\circ} \mathrm{C}$ & -105.6 & -90.1 & -67.5 & -50.2 & & & \\
\hline & $I_{\max } / \mathrm{pA}$ & 2.7 & 20.6 & 25 & 20.8 & & & \\
\hline & $\Delta \varepsilon$ & 0.02 & 0.18 & 0.31 & 0.19 & & & \\
\hline \multirow[t]{3}{*}{ cast } & $\vartheta_{\max } /{ }^{\circ} \mathrm{C}$ & -101 & -83 & -70.5 & -62.5 & -27 & -14.5 & \\
\hline & $I_{\max } / \mathrm{pA}$ & 6.2 & 13.4 & 92.5 & 771 & 80 & 11 & \\
\hline & $\Delta \varepsilon$ & 0.06 & 0.1 & 0.46 & 2.3 & 0.49 & 0.96 & \\
\hline \multirow[t]{3}{*}{ oliv } & $\vartheta_{\max } /{ }^{\circ} \mathrm{C}$ & & -86 & -64 & -36 & & 8.3 & \\
\hline & $I_{\max } / \mathrm{pA}$ & & 20.5 & 16 & 17 & & 180 & \\
\hline & $\Delta \varepsilon$ & & 0.19 & 0.23 & 0.19 & & 2.15 & \\
\hline \multirow[t]{3}{*}{ palm } & $\vartheta_{\max } /{ }^{\circ} \mathrm{C}$ & & -87.5 & -64.9 & -2.2 & 6.6 & 23.6 & 27.1 \\
\hline & $I_{\max } / \mathrm{pA}$ & & 7.6 & 28 & 253 & 246 & 970 & 1160 \\
\hline & $\Delta \varepsilon$ & & 0.1 & 0.31 & 1.5 & 0.55 & 2.9 & 4.2 \\
\hline \multirow[t]{3}{*}{ sun } & $\vartheta_{\max } /{ }^{\circ} \mathrm{C}$ & -109 & -93.2 & & -25.2 & -11.4 & & \\
\hline & $I_{\max } / \mathrm{pA}$ & 5.6 & 31.5 & & 780 & 752 & & \\
\hline & $\Delta \varepsilon$ & 0.02 & 0.26 & & 1.6 & 1.7 & & \\
\hline
\end{tabular}

\section{Conclusions}

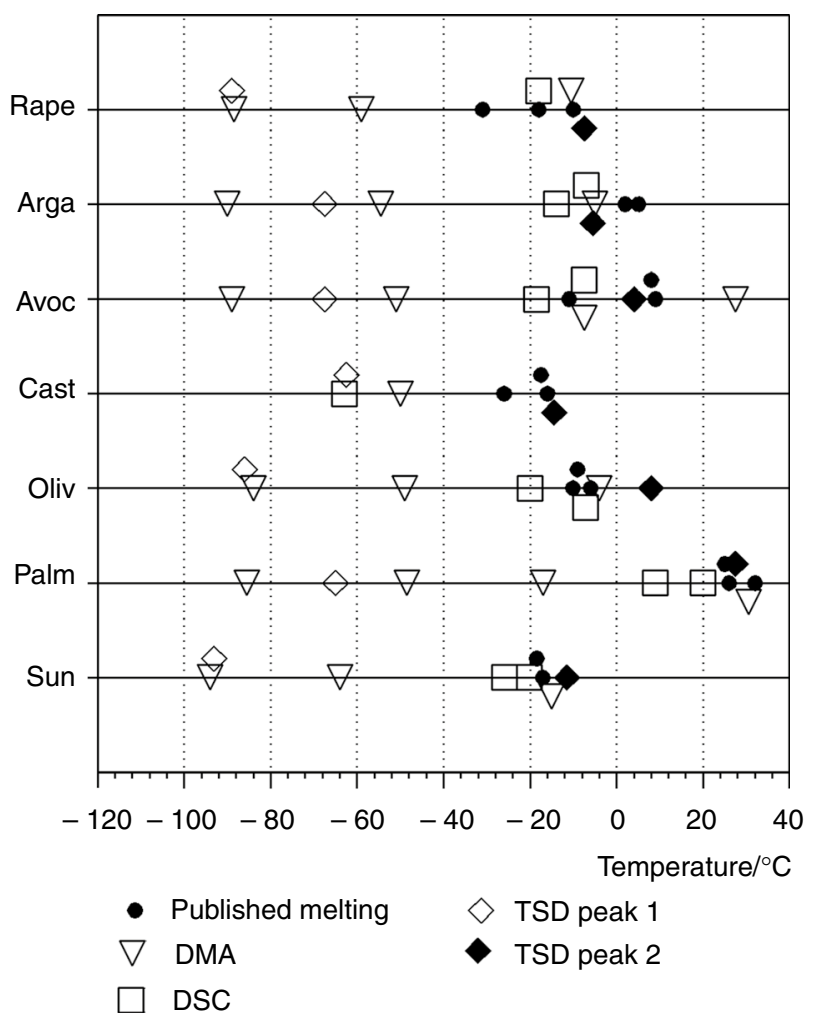

Fig. 11 Summarized peak temperatures of DSC, DMA and TSD tests compared to literature values
Using scaffolds of high porosity allows simple execution for both DMA and TSD measurements. Neither the borosilicate for the TSD nor the cellulose for the DMA tests produced artifacts. Because the DMA $\operatorname{tg} \delta$ curve of castor oil does not contain any transition below its glass transition, lower temperature peaks of other oils must be originating from the oil and not from the cellulose scaffold.

Because depolarization current of borosilicate glass filter is less than $1 \mathrm{pA}$ below $0{ }^{\circ} \mathrm{C}$ [15], low-temperature transitions are also originated from the oil.

We suggest that the origin of these low-temperature transitions is a small-scale conformational movement of few carbon atom length chains. Length and symmetry of these segments depend on the distance from polar groups, for example, the ester groups.

Although the fatty acid composition of oils was determined, the exact triglyceride structure is unknown. Three different fatty acids can form 15 different triglycerides; therefore, the structure of plant oils is more complicated than expected. Considering the fatty acids below $5 \%$, the number of possible compounds is much higher.

Castor oil has the most uniform fatty acid composition. Interestingly, in spite of the most regular structure, it shows typical glass transition and not crystalline melting. Other than that, glass transition can only be detected by 
the TSD method. Although ricinoleic acid is a hydroxy acid, the relaxation strength of glass transition is not as high as expected. In spite of its higher polarity, the $-\mathrm{OH}$ group might hinder the conformational movements at low temperatures.

The current reversal may be an important occurrence but current studies cannot answer the question: What is the reason for this symptom? In general, a current reversal occurs in the case of layered samples or in the presence of an air gap. Air gap can be excluded in the electrode arrangement used. Partial solidification might produce phase separation building up locally layered structures. It can be visually observed in case of some animal fats. This satisfies the condition of nonzero internal field. We suppose that low-temperature $\mathrm{X}$-ray diffraction could help to elaborate, but this method is not available for us at present.

Test results and literature values are summarized in Fig. 11. It shows that the results of the present study are sometimes far from the literature values. We take it for important that even in these relatively low molecular weight material several relaxation processes appear, and it is worth to continue this research. The nature of transitions below $-40{ }^{\circ} \mathrm{C}$ could be revealed by testing the pure triglycerides.

Acknowledgements The research was carried out as part of the EFOP3.6.1-16-2016-00011 "Younger and Renewing University-Innovative Knowledge City-institutional development of the University of Miskolc aiming at intelligent specialization" project implemented in the framework of the Széchenyi 2020 program. The realization of this project is supported by the European Union, co-financed by the European Social Fund. The authors also acknowledge the BorsodChem Zrt for allowing the execution of part of this project at their Technological Support laboratory; and additionally Gábor Muránszky at the Institute of Chemistry who helped to carry out gas chromatography measurements.

Funding Open Access funding provided by University of Miskolc.

Open Access This article is licensed under a Creative Commons Attribution 4.0 International License, which permits use, sharing, adaptation, distribution and reproduction in any medium or format, as long as you give appropriate credit to the original author(s) and the source, provide a link to the Creative Commons licence, and indicate if changes were made. The images or other third party material in this article are included in the article's Creative Commons licence, unless indicated otherwise in a credit line to the material. If material is not included in the article's Creative Commons licence and your intended use is not permitted by statutory regulation or exceeds the permitted use, you will need to obtain permission directly from the copyright holder. To view a copy of this licence, visit http://creativecommons .org/licenses/by/4.0/.

\section{References}

1. Pradhan A, Shrestha DS, McAloon A, Yee W, Haas M, Duffield JA. Energy life-cycle assessment of soybean biodiesel revisited. Trans ASABE. 2011;54(3):1031-9. ISSN: 2151-0032.

2. Adam SA, Fairuz MA, Hussin MS, Hafiezal MRM, Khaironisa SN. Investigate the effect of using sunflower oil as a lubricant during turning operation of stainless steel. Int Rev Mech Eng. 2014;8:22-7.

3. Syahrullail S, Zubil BM, Azwadi CSN, Ridzuan MJM. Experimental evaluation of palm oil as lubricant in cold forward extrusion process. Int J Mech Sci. 2011. https://doi.org/10.1016/j. ijmecsci.2011.05.002.

4. Bartha Z, Gumiipari kézikönyv I. (Handbook of rubber industry), TAURUS-OMIKK, Budapest; 1988. p. 226-44 (in Hungarian). ISBN: 9635-927-231.

5. Jia P, Zhang M, Hu L, Liu C, Feng G, Yang X, Bo C, Zho Y. Development of a vegetable oil based plasticizer for preparing flame retardant poly(vinyl chloride) materials. RSC Adv. 2015. https://doi.org/10.1039/C5RA10509A.

6. Haryono A, Triwulandari E, Jiang P. Interaction between vegetable oil based plasticizer molecules and polyvinyl chloride, and their plasticization effect. AIP Conf Proc. 2017. https://doi. org/10.1063/1.4973172.

7. Jin $\mathrm{ZH}, \mathrm{Lu} \mathrm{K}$. Encyclopedia of materials: science and technology. 2nd ed. 2002. p. 1-8. https://doi.org/10.1016/B0-08-04315 2-6/01844-1.

8. Tseretely GI, Smirnova OI. DSC study of melting and glass transition in gelatins. J Therm Anal. 1992. https://doi.org/10.1007/ BF01979179.

9. Correia NT, Alvarez C, Moura Ramos JJ, Descamps M. Molecular motions in molecular glasses as studied by thermally stimulated depolarisation currents (TSDC). Chem Phys. 2000. https ://doi.org/10.1016/S0301-0104(99)00354-7.

10. Bansak N, Dhaliwal AS, Mann KS. Dielectric characterization of rapeseed (Brassica nalus L.) from 10 to $3000 \mathrm{MHz}$. Biosyst Eng. 2016. https://doi.org/10.1016/j.biosystems eng.2015.12.014.

11. Hedvig P. Dielectric spectroscopy of polymers Bristol, Hilger; 1977. ISBN:963-05-0481-2.

12. Eder K. Gas chromatographic analysis of fatty acid methyl esters. J Chromatogr B Biomed Appl. 1995;671(1-2):11331. https://doi.org/10.1016/0378-4347(95)00142-6 (PMID: 8520689).

13. Ihemaguba CL. Using physical methods for the investigation and characterization of fine structure of fluid additives and selected polymeric materials, MSc Thesis 2018 University of Miskolc. (in English).

14. Ihemaguba CL, Marossy K. Combined thermal analysis of fluid plasticizers. J Therm Anal Calorim. 2020. https://doi. org/10.1007/s10973-020-10315-8.

15. Marossy K. Practical approach to thermally stimulated discharge (TSD) method on polymers. J Therm Anal Calorim. 2017. https ://doi.org/10.1007/s10973-017-6098-6.

16. https://www.engineeringtoolbox.com/oil-melting-point-d_1088. html. Accessed 10 May 2020

17. http://www.veganbaking.net/articles/tools/fat-and-oil-melt-point -temperatures. Accessed 10 May 2020.

18. Asadauskas S, Erhan SZ. Depression of pour points of vegetable oils by blending with diluents used for biodegradable lubricants. J Am Oil Chem Soc. 1999. https://doi.org/10.1007/ s11746-999-0237-6. 
19. Chinchkar DS, Satpute ST, Kumbhar NR. Castor oil as green lubricant: a review. Int J Eng Res Technol IJERT. 2012;1(5):2. ISSN: 2278-0181.

20. https://sheavaj.hu/arganolaj. Accessed 05 May 2020.

21. Folayan AJ, Anawe PAL. Synthesis and characterization of Argania spinosa (Argan oil) biodiesel by sodium hydroxide catalyzed transesterification reaction as alternative for petro-diesel in direct injection, compression ignition engines. Heliyon. 2019. https://doi.org/10.1016/j.heliyon.2019.e02427.

22. https://www.sciencedirect.com/topics/agricultural-and-biolo gical-sciences/avocado-oil. Accessed 02 Mar 2020.

23. https://www.chemicalbook.com/ChemicalProductProperty_US_ CB4411776.aspx. Accessed 02 Mar 2020.

24. Manaf YN, Rahardjo AP, Yusof YA, Desa MNM, Nusantoro BP. Lipid characteristics and tocopherol content of the oils of native avocado cultivars grown in Indonesia. Int J Food Prop. 2018. https://doi.org/10.1080/10942912.2018.1564761.

25. Ács I. A gépkocsi-fékfolyadék múszaki fejlesztése (Technological development of vehicle break fluid). Hadtápbiztosítás. 1977;4(1): 17 (in Hungarian).
26. https://en.m.wikipedia.org/wiki/Castor_oil. Accessed 02 Mar 2020.

27. Devi A, Khatkar BS. Physicochemical, rheological and functional properties of fats and oils in relation to cookie quality: a review. J Food Sci Technol. 2016. https://doi.org/10.1007/s1319 7-016-2355-0.

28. Bushnan I, Singh VK, Triphati DK. Nanomaterials and environmental biotechnology. Springer, Ch. 18; 2020. p. 342. ISBN: 978-3-030-34543-3.

29. http://www.palmoilworld.org/about_palmoil.html. Accessed 02 Mar 2020.

30. https://www.chemicalbook.com/ChemicalProductProperty_EN_ cb1317071.htm. Accessed 02 Mar 2020.

Publisher's Note Springer Nature remains neutral with regard to jurisdictional claims in published maps and institutional affiliations. 